\title{
Constitutive Activity of the Serotonin2C Receptor Inhibits In Vivo Dopamine Release in the Rat Striatum and Nucleus Accumbens
}

\author{
Philippe De Deurwaerdère, ${ }^{1}$ Sylvia Navailles, ${ }^{1}$ Kelly A. Berg, ${ }^{2}$ William P. Clarke, ${ }^{2}$ and Umberto Spampinato ${ }^{1}$ \\ ${ }^{1}$ Unité Mixte de Recherche Centre National de la Recherche Scientifique 5541-Université Victor Segalen Bordeaux 2, Boîte Postale 31, 33076 Bordeaux \\ Cedex, France, and ${ }^{2}$ Department of Pharmacology, University of Texas, Health Science Center, San Antonio, Texas 78229-3900
}

\begin{abstract}
Numerous research has pointed out that serotonin $2 \mathrm{c}\left(5-\mathrm{HT}_{2 \mathrm{C}}\right)$ receptor, a subtype of 5-HT receptors belonging to the G-protein-coupled receptor superfamily, modulates the activity of mesencephalic dopamine (DA) neurons, the dysfunction of which is involved in devastating diseases such as schizophrenia, Parkinson's disease, and drug addiction. In the present study, using in vivo intracerebral microdialysis and Chinese hamster ovary $(\mathrm{CHO})$ cells expressing $5-\mathrm{HT}_{2 \mathrm{C}}$ receptors to identify appropriate $5-\mathrm{HT}_{2 \mathrm{C}}$ receptor ligands, we sought to determine whether the property of $5-\mathrm{HT}_{2 \mathrm{C}}$ receptors to spontaneously activate intracellular signaling pathways in vitro (constitutive activity) participates in the tonic inhibitory control that they exert on DA release in the rat striatum and nucleus accumbens in vivo. In CHO cells, the purported antagonist 5-methyl-1-(3-pyridylcarbamoyl)-1,2,3,5-tetrahydropyrrolo[2,3-f] indole hydrochloride (SB 206553), but not 6-chloro-5-methyl-1-[6-(2-methylpiridin-3-yloxy)pyridin-3-yl carbamoyl] indoline (SB 242084), decreased basal inositol phosphate accumulation, thus behaving as a $5-\mathrm{HT}_{2 \mathrm{C}}$ inverse agonist. Its effect was prevented by SB 242084. In vivo, SB 206553 (1-10 $\mathrm{mg} / \mathrm{kg}$ ) elicited a dose-dependent and clear-cut increase in accumbal and striatal DA release compared with SB $242084(1-10 \mathrm{mg} / \mathrm{kg})$, and the 5- $\mathrm{HT}_{2 \mathrm{C}}$ agonist S-2-(6-chloro-5-fluoroindol-1-yl)-1-methylethylamine hydrochloride (Ro-60-0175) (0.3-3 mg/kg) inhibited DA release. Pretreatment by SB 242084 reversed the change in DA release elicited by Ro-60-0175 and SB 206553. Furthermore, SB 206553stimulated DA release was insensitive to reduction of 5-HT neuronal function induced by the 5- $\mathrm{HT}_{1 \mathrm{~A}}$ agonist ( \pm )-8-hydroxy-2dipropylaminotetralin or intra-raphe injections of 5,7-dihydroxytryptamine neurotoxin. The obtained results provide the first in vivo evidence that constitutive activity of the 5- $\mathrm{HT}_{2 \mathrm{C}}$ receptor tonically inhibits mesencephalic DA neurons and underscore the need for a better understanding of the pathophysiological role of constitutive receptor activity.
\end{abstract}

Key words: DA release; striatum; nucleus accumbens; $5-\mathrm{HT}_{2 \mathrm{C}}$ receptor; rat; constitutive activity

\section{Introduction}

Precise control of ascending mesencephalic dopamine (DA) neurons is critical for normal brain function, and aberration in their functional status contributes to various devastating diseases and conditions such as schizophrenia, Parkinson's disease, and drug addiction (Dunnett and Robbins, 1992; Di Chiara, 2002). It is well established that the central serotonin (5-HT) system controls DA neuron activity (Soubrié et al., 1984; Kapur and Remington, 1996). Evidence indicates that the $5-\mathrm{HT}_{2 \mathrm{C}}$ receptor, a 5-HT receptor subtype belonging to the G-protein-coupled receptor superfamily and expressed to a large extent along ascend-

Received Sept. 16, 2003; revised Feb. 13, 2004; accepted Feb. 13, 2004

This work was supported by grants from Centre National de la Recherche Scientifique-Bordeaux 2 University, the National Institutes of Health (GM 58652), and the National Alliance for Research on Schizophrenia and Depression Foundation. We are grateful to Dr. M. Wood (Psychiatry, Centre of Excellence for Drug Discovery, GlaxoSmithKline, Harlow, UK) for the gift of SB 242084, and to Dr. P. Weber (Hoffmann-La Roche, Basel, Switzerland) for the gift of Ro-60-0175. We thank Dr. G. Porras, D. Moison, J. Cropper, and B. King for their technical assistance.

Correspondence should be addressed to Prof. U. Spampinato, Unité Mixte de Recherche Centre National de la Recherche Scientifique 5541-Université Victor Segalen Bordeaux 2, 146 rue Léo Saignat, Boîte Postale 31, 33076 Bordeaux Cedex, France. E-mail: umberto.spampinato@|npb.u-bordeaux2.fr.

DOI:10.1523/JNEUROSCI.0112-04.2004

Copyright $\odot 2004$ Society for Neuroscience $\quad$ 0270-6474/04/243235-07\$15.00/0 ing DA pathways (Eberle-Wang et al., 1997; Barnes and Sharp, 1999), plays a prominent role in this interaction and represents a useful target for improved treatment of neuropsychiatric disorders related to DA neuron dysfunctions (De Deurwaerdère and Chesselet, 2000; Grottick et al., 2000; Wood et al., 2001).

In vivo electrophysiological and biochemical studies have shown that $5-\mathrm{HT}_{2 \mathrm{C}}$ agonists and antagonists inhibit and enhance, respectively, basal DA cell firing and DA release at terminals (Di Giovanni et al., 1999; Gobert et al., 2000; De Deurwaerdère and Spampinato, 2001). The tonic inhibitory control revealed by purported antagonists has been classically attributed to blockade of endogenous 5-HT action at 5- $\mathrm{HT}_{2 \mathrm{C}}$ receptors (Di Giovanni et al., 1999). Nevertheless, the magnitude of this effect differs across the antagonists (De Deurwaerdère and Spampinato, 2001), and these different responses are not solely related to different selectivity of antagonists toward 5- $\mathrm{HT}_{2 \mathrm{C}}$ receptors (Di Giovanni et al., 1999; Gobert et al., 2000). It is possible, as suggested previously (Willins and Meltzer, 1998), that the 5- $\mathrm{HT}_{2 \mathrm{C}}$ receptor-dependent control of basal DA neuron activity is not related strictly to 5-HT extracellular levels.

Studies conducted in heterologous expression systems have demonstrated the considerable ability of the native $5-\mathrm{HT}_{2 \mathrm{C}}$ re- 
ceptor to spontaneously activate intracellular signaling pathways, including phospholipase C (PLC) and phospholipase A2 ( $\left.\mathrm{PLA}_{2}\right)$, in the absence of agonist stimulation (Barker et al., 1994; Berg et al., 1999; Niswender et al., 1999). Most drugs previously thought to be antagonists at the $5-\mathrm{HT}_{2 \mathrm{C}}$ receptor are capable of silencing its constitutive activity in vitro, behaving as inverse agonists (Berg et al., 1999; Herrick-Davis et al., 1999). Interestingly, the prototypical $5-\mathrm{HT}_{2 \mathrm{C}}$ inverse agonist 5-methyl-1-(3-pyridylcarbamoyl)-1,2,3,5tetrahydropyrrolo[2,3-f] indole hydrochloride (SB 206553) is one of the most efficient drugs to enhance DA release in vivo (Gobert et al., 2000 ), raising the hypothesis that constitutive activity of $5-\mathrm{HT}_{2 \mathrm{C}}$ receptors could regulate DA neuron activity in vivo.

To test this hypothesis, according to the pharmacological properties inherent in the constitutive activity of G-proteincoupled receptors (Lefkowitz et al., 1993), we have evaluated the ability of a putative neutral $5-\mathrm{HT}_{2 \mathrm{C}}$ antagonist 6-chloro-5methyl-1-[6-(2-methylpiridin-3-yloxy)pyridin-3-yl carbamoyl] indoline (SB 242084) to reverse the effect induced by both the prototypical $5-\mathrm{HT}_{2 \mathrm{C}}$ inverse agonist SB 206553 and the $5-\mathrm{HT}_{2 \mathrm{~B} / 2 \mathrm{C}}$ agonist S-2-(6-chloro-5-fluoroindol-1-yl)-1-methylethylamine hydrochloride (Ro-60-0175) on in vivo DA release (Kennett et al., 1996, 1997; Martin et al., 1998). Pharmacological profile of ligands was studied in Chinese hamster ovary $(\mathrm{CHO})$ cells expressing $5-\mathrm{HT}_{2 \mathrm{C}}$ receptors. In vivo DA release was measured simultaneously in the ipsilateral nucleus accumbens and striatum using intracerebral microdialysis in halothane-anesthetized rats (De Deurwaerdère et al., 1998) to evaluate possible differences in the $5-\mathrm{HT}_{2 \mathrm{C}}$ receptor control of the mesoaccumbens and the nigrostriatal DA pathways (Di Matteo et al., 2001).

\section{Materials and Methods}

Animals. Male Sprague Dawley rats (Iffa Credo, Lyon, France) weighing $330-380$ gm were used. Animals were kept at constant room temperature $\left(21 \pm 2^{\circ} \mathrm{C}\right)$ and relative humidity $(60 \%)$ with a 12 light/dark cycle (dark from 8 P.M.) and had ad libitum access to water and food. All animal procedures conformed to International European Ethical Standards (86/ 609-EEC) and the French National Committee (décret 87/848) for the care and use of laboratory animals. All efforts were made to minimize animal suffering and reduce the number of animals used.

Cell culture. CHO-1C19 and CHO-1C7 cells are CHO-K1-derived cell lines that stably express human $5-\mathrm{HT}_{2 \mathrm{C}}$ receptors at a density of $\sim 250$ $\mathrm{fmol} / \mathrm{mg}$ protein and $\sim 10-20 \mathrm{pmol} / \mathrm{mg}$ protein, respectively (Berg et al., 1999). Cells were maintained in $\alpha$-MEM supplemented with 5\% FBS and $300 \mu \mathrm{g} / \mathrm{ml}$ hygromyocin. For these experiments, the cells were seeded into multiwell tissue culture plates at a density of $4 \times 10^{4} \mathrm{cells} / \mathrm{cm}^{2}$. After a $24 \mathrm{hr}$ plating period, cells were washed with HBSS and placed into DMEM/F-12 (1:1) with $5 \mu \mathrm{g} / \mathrm{ml}$ insulin, $5 \mu \mathrm{g} / \mathrm{ml}$ transferrin, $30 \mathrm{nM}$ selenium, $20 \mathrm{~nm}$ progesterone, and $100 \mu \mathrm{M}$ putrescine (serum-free media). Cells were grown in serum-free media for $24 \mathrm{hr}$ before experimentation.

Inositol phosphate accumulation and arachidonic acid release measurements. Cells were labeled with $1 \mu \mathrm{Ci} / \mathrm{ml}$ myo- $\left[{ }^{3} \mathrm{H}\right]$ inositol in serum-free medium for $24 \mathrm{hr}$ and $0.1 \mu \mathrm{Ci} / \mathrm{ml}\left[{ }^{3} \mathrm{H}\right]$ arachidonic acid (AA) for $4 \mathrm{hr}$. Total inositol phosphate accumulation $\left(\mathrm{IP}_{1}, \mathrm{IP}_{2}, \mathrm{IP}_{3}\right.$, collectively referred to as IP) and AA release were measured as described previously (Berg et al., 1999). Measurements of PLC-mediated IP accumulation and $\mathrm{PLA}_{2}-$ mediated AA release were made simultaneously from the same multiwell. The assay was begun by adding experimental media [HBSS containing calcium and magnesium supplemented with $20 \mathrm{~mm}$ HEPES, $20 \mathrm{~mm} \mathrm{LiCl}$, and $0.01 \%$ fatty-acid-free bovine serum albumin (BSA)]. After a $25 \mathrm{~min}$ incubation, $200 \mu \mathrm{l}$ aliquots of media from each well were added directly to scintillation vials for measurement of $\left[{ }^{3} \mathrm{H}\right]$ content (AA release) with liquid scintillation counting. The remaining media was aspirated quickly, and $2 \mathrm{ml}$ of $10 \mathrm{~mm}$ formic acid was added to extract the accumulated $\left[{ }^{3} \mathrm{H}\right]$-IPs. The $\left[{ }^{3} \mathrm{H}\right]$-IPs were separated with ion exchange chromatography and quantified with liquid scintillation counting. $\left[\gamma^{35}\right.$ S ] GTP binding. $\left[\gamma^{35}\right.$ S]GTP binding was performed as described previously (Evans et al., 2001). Briefly, after $24 \mathrm{hr}$ in serum-free media, cells in $15 \mathrm{~cm}$ plates $(\sim 320 \mu \mathrm{g}$ of total protein) were washed twice with ice-cold HBSS, scraped, and pelleted. Pellets were flash frozen and stored in liquid nitrogen. Membranes were prepared by repeated trituration of thawed cell pellets through a $1 \mathrm{ml}$ pipette in ice-cold wash buffer $(20 \mathrm{~mm}$ HEPES, 3 mM $\mathrm{MgCl}_{2}, 0.2 \mathrm{~mm}$ EGTA, and $100 \mathrm{~mm} \mathrm{NaCl}, \mathrm{pH} 7.4$ at $23^{\circ} \mathrm{C}$ ). The homogenate was centrifuged $\left(39,000 \times g ; 4^{\circ} \mathrm{C} ; 10 \mathrm{~min}\right)$, and the pellet was washed two times by resuspension in $40 \mathrm{vol}$ of the same buffer and centrifugation. Membranes were resuspended in assay buffer [wash buffer plus GDP $(10 \mu \mathrm{M})$, okadaic acid (100 nM), and cypermethrin (10 $\mathrm{nM})]$ at a protein concentration of $50 \mu \mathrm{g} / \mathrm{ml}$. Aliquots $(100 \mu \mathrm{l})$ of the membrane suspension were preincubated with the test compound or vehicle (assay buffer) in Millipore 96-well Multiscreen filtration plates for $30 \mathrm{~min}$ at $37^{\circ} \mathrm{C}$ in triplicate. The assay was initiated by the addition of $\left[\gamma^{35} \mathrm{~S}\right]$ GTP (final concentration of $0.3 \mathrm{~nm}$ ). The assay was terminated after $30 \mathrm{~min}$ by rapid filtration and subsequent washing of filters (eight times with $200 \mu \mathrm{l}$ each) with ice-cold wash buffer. Filters from the plates were removed, placed in scintillation vials, and counted with a Beckman LS7500 liquid scintillation counter. $5-\mathrm{HT}_{2 \mathrm{C}}$ receptor-mediated $\left[\gamma^{35} \mathrm{~S}\right]$ GTP binding was completely abolished by pretreatment of cells with pertussis toxin $(50 \mathrm{ng} / \mathrm{ml}, 24 \mathrm{hr})$. Nonspecific binding was determined in the presence of guanosine $5^{\prime}$ - $(\beta, \gamma$-imido)triphosphate ( $1 \mathrm{~mm})$. Protein determination was according to the method of Bradford.

Microdialysis. Surgery and perfusion procedures were performed as described previously (Porras et al., 2002), with minor modifications. Briefly, rats were anesthetized with a mixture of halothane and nitrous oxide-oxygen $(2 \% ; 2: 1, \mathrm{v} / \mathrm{v})$. After tracheotomy for artificial ventilation, the animals were placed in a stereotaxic frame, and their rectal temperature was monitored and maintained at $37.3 \pm 0.1^{\circ} \mathrm{C}$ with a heating pad. Two microdialysis probes, 2 and $4 \mathrm{~mm}$ long, (CMA/11, $240 \mu \mathrm{m}$ outer diameter; Cuprophan; Carnegie Medicin, Phymep, Paris, France) were implanted simultaneously using a dual probe holder (Carnegie Medicin, Phymep) in the right nucleus accumbens and striatum [respective coordinates from interaural point (Paxinos and Watson, 1998): anteroposte$\operatorname{rior}(\mathrm{AP})=11$ and $9.8 ;$ lateral $(\mathrm{L})=1.3$ and 3.3 ; ventral $(\mathrm{V})=2$ and 2.8$]$. Probes were perfused at a constant flow rate of $2 \mu \mathrm{l} / \mathrm{min}$ by means of a microperfusion pump (CMA 100, Carnegie Medicin, Phymep) with artificial CSF containing (in $\mathrm{mm}$ ): $154.1 \mathrm{Cl}^{-}, 147 \mathrm{Na}^{+}, 2.7 \mathrm{~K}^{+}, 1 \mathrm{Mg}^{2+}$, and $1.2 \mathrm{Ca}^{2+}$, adjusted to $\mathrm{pH} 7.4$ with $2 \mathrm{~mm}$ sodium phosphate buffer. Dialysates $(30 \mu \mathrm{l})$ were collected on ice every $15 \mathrm{~min}$. The in vitro recoveries of the probes were $\sim 10 \%$ for DA. At the end of each experiment, the brain was removed and fixed in $\mathrm{NaCl}(0.9 \%)$ /paraformaldehyde solution (10\%). The location of the probes was determined histologically on serial coronal sections $(60 \mu \mathrm{m})$ stained with cresyl violet, and only data obtained from rats with correctly implanted probes were included in the results.

Lesion of 5-HT neurons by 5,7-dihydroxytryptamine. Lesion of 5-HT neurons was performed by two bilateral injections of 5,7dihydroxytryptamine (5,7-DHT) into the dorsal raphe nucleus (DRN), a protocol that has been shown to produce an almost complete and selective depletion of endogenous 5-HT in the brain (De Deurwaerdère et al., 1998). Briefly, rats initially weighing 260-280 gm were anesthetized with chloral hydrate ( $400 \mathrm{mg} / \mathrm{kg}$, i.p.) and immobilized in a stereotaxic apparatus. Four micrograms of 5,7-DHT, calculated as free base, dissolved in $2 \mu \mathrm{l}$ of $0.9 \%$ saline containing $0.1 \%$ ascorbic acid, were delivered through two stainless-steel cannulas ( 30 ga) placed on each DRN side at a constant flow rate of $0.5 \mu \mathrm{l} / \mathrm{min}$. Stereotaxic coordinates $(\mathrm{AP}=+0.8 /-0.2 ; \mathrm{L}=$ $\pm 0.5 ; \mathrm{V}=+2.5 /+2.3$, with respect to the interaural point) were determined according to the Pellegrino and Cushman (1967) atlas to avoid damage of the sinus when the two stainless-steel cannulas were lowered into the DRN. Sham-lesioned animals received an identical volume of vehicle alone. To prevent damage to the noradrenergic system, all of the animals were given an intraperitoneal administration of desmethylimipramine $(25 \mathrm{mg} / \mathrm{kg}$, as the salt) $30-45 \mathrm{~min}$ before $5,7-\mathrm{DHT}$ injection (Baumgarten et al., 1973). Dialysis experiments were performed 18-21 d after surgery.

In each animal, the efficacy of 5,7-DHT treatment to impair central 
5-HT transmission was evaluated in vivo by monitoring 5-hydroxyindolacetic acid (5-HIAA) extracellular levels, which have been shown to correlate positively with the magnitude of central 5-HT neuron depletion (Kirby et al., 1995; De Deurwaerdère et al., 1998). Only data obtained from lesioned rats having at least a $90 \%$ decrease in basal 5-HIAA extracellular levels compared with sham-lesioned rats were included in the results (five of eight animals).

Chromatographic analysis. Dialysate samples were immediately analyzed by reverse-phase HPLC coupled with electrochemical detection, as described previously (Porras et al., 2002). The mobile phase [containing (in mM): $70 \mathrm{NaH}_{2} \mathrm{PO}_{4}, 0.1 \mathrm{Na}_{2} \mathrm{EDTA}, 0.7$ triethylamine, and 0.1 octylsulfonic acid plus $10 \%$ methanol, adjusted to $\mathrm{pH} 4.8$ with ortophosphoric acid] was delivered at $1 \mathrm{ml} / \mathrm{min}$ flow rate (system LC-10AD-VP, Shimadzu, Duisburg, France) through a Hypersyl column $(\mathrm{C} 18 ; 4.6 \times$ $150 \mathrm{~mm}$; particle size $5 \mu \mathrm{m}$; Touzard and Matignon, Paris, France). Detection of DA, and 5-HIAA in some experiment, was performed with a coulometric detector (Coulochem II, ESA, Paris, France) coupled to a dual-electrode analytical cell (model 5014, ESA). The potential of the electrodes was set at -175 and $+175 \mathrm{mV}$. Output signals were recorded on a computer (system class VP-4, Shimadzu). Under these conditions, the sensitivity for DA and 5-HIAA was 0.5 and $2 \mathrm{pg} / 30 \mu \mathrm{l}$, respectively, with a signal/noise ratio of $3: 1$.

Pharmacological treatment. Pharmacological treatments were performed after the stabilization of DA levels in the perfusate. A stable baseline, defined as three consecutive samples in which DA contents varied by $<10 \%$ in both structures, was generally obtained $120 \mathrm{~min}$ after the beginning of the perfusion (stabilization period). In case of coadministration, SB 242084 or its vehicle was injected 30 min before SB 206553 or Ro-60-0175, SB 206553 was administered 30 min before Ro-600175, and ( \pm )-8-hydroxy-2-dipropylaminotetralin (8-OH-DPAT) was administered 5 min before SB 206553. Ro-60-0175 and 8-OH-DPAT were dissolved in a physiological saline $(\mathrm{NaCl} 0.9 \%)$, SB 206553 was dissolved in a 99:1 v/v mixture of apyrogenic water and lactic acid, and SB 242084 was dissolved in a mixture of physiological saline $(\mathrm{NaCl} 0.9 \%)$ containing hydroxypropyl- $\beta$-cyclodextrin ( $8 \%$ by weight) plus citric acid $(25 \mathrm{~mm})$. All drugs were injected intraperitoneally with the exception of 8-OH-DPAT (subcutaneously), and all drug doses were calculated as the free base. In each experimental group, animals received either drugs or their appropriate vehicle.

Statistical analysis. DA content in each sample was expressed as the percentage of the average baseline level calculated from the three fractions preceding any treatment. Data correspond to the mean \pm SEM values of the percentage obtained in each experimental group. The overall effect corresponds to the average of percentages of baseline for dialysates collected after the administration of pharmacological treatments.

The statistical analysis of the effect elicited by $5-\mathrm{HT}_{2 \mathrm{C}}$ agents alone on DA release was performed by a one-way ANOVA with time as repeated measures (10 samples). To determine an interaction between two drugs on DA release, a two-way ANOVA using the two treatments as the main factors and time as repeated measures (eight samples) was performed. The ability of 5,7-DHT lesion to modify basal DA and 5-HIAA dialysate content from the nucleus accumbens and striatum and the effect of SB 206553 was studied by using a one-way ANOVA. Also, a one-way ANOVA was performed for each experiment to determine whether absolute DA levels were homogenous across groups. Finally, in the case of a significant result of the ANOVAs $(p<0.05)$, the ANOVA was followed by the Fisher's protected least significance difference post hoc test (Fisher's PLSD) to allow adequate multiple comparisons between groups.

Drugs. The following compounds were used: Ro-60-0175 kindly donated by Dr. P. Weber (Hoffmann-La Roche, Basel, Switzerland); SB 242084 [generously provided by Dr. M. Wood (Psychiatry, Centre of Excellence for Drug Discovery, GlaxoSmithKline, Harlow, UK]; SB 206553, ( \pm )8-OH-DPAT hydrobromide, 5,7-DHT creatinine sulfate, and desmethylimipramine hydrochloride were purchased from Research Biochemicals (Natick, MA). All other chemicals and reagents were the purest commercially available (Sigma, St. Louis, MO; VWR, Strasbourg, France; Tocris, Strasbourg, France).
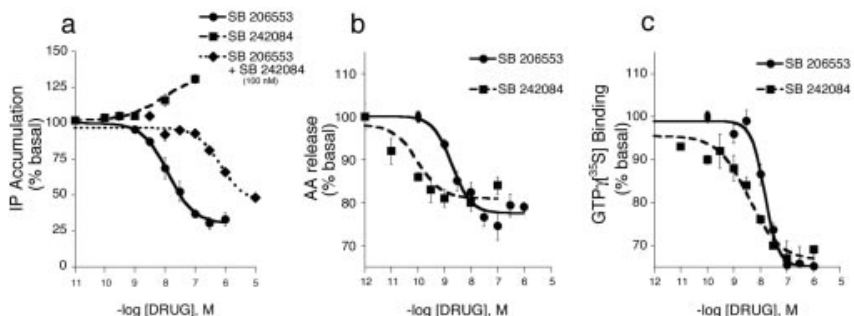

Figure 1. Pharmacological properties of SB 206553 and SB 242084 in CHO-1C7 cells. Cells, prelabeled with $\left[{ }^{3} \mathrm{H}\right]-\mathrm{AA}$ and myo- $\left[{ }^{3} \mathrm{H}\right]$ inositol, were incubated with the indicated drugs for 25 min in the presence of LiCL $(20 \mathrm{~mm})$ and $0.1 \%$ fatty acid-free BSA. $a-c$, Concentration-response curves for SB 242084 and SB 206553 measuring IP accumulation [SB 206553 alone and in the presence of $100 \mathrm{~nm}$ SB $242084(a)$ ], AA release ( $b$ ), or [ $\gamma^{35}$ S] GTP binding (c). Basal IP accumulation, AA release, and $\left[\gamma^{35} \mathrm{~S}\right] \mathrm{GTP}$ binding levels were as follows: $1544 \pm 167 \mathrm{dpm}, 5378 \pm 789$ $\mathrm{dpm}$, and $72 \pm 13 \mathrm{pmol} / \mathrm{mg}$ protein, respectively. Data are expressed as the mean \pm SEM of six $(a, b)$ or four $(c)$ independent experiments.

\section{Results}

\section{Pharmacological characterization of $5-\mathrm{HT}_{2 \mathrm{C}}$ agents in $\mathrm{CHO}$} cells expressing the human $5-\mathrm{HT}_{2 \mathrm{C}}$ receptor

The objective of this set of experiments was to characterize the efficacy properties (positive $=$ agonist, negative $=$ inverse agonist, and $0=$ neutral antagonist) of two purported $5-\mathrm{HT}_{2 \mathrm{C}}$ antagonists in $\mathrm{CHO}-1 \mathrm{C} 7$ cells. The efficacy of 5- $\mathrm{HT}_{2 \mathrm{C}}$ ligands was measured on three independent signaling pathways; PLC was assessed by monitoring IP accumulation, PLA $_{2}$ was assessed by measuring AA release, and activation of $\mathrm{G} \alpha_{\mathrm{i}}$ was assessed with $\left[\gamma^{35}\right.$ S $]$ GTP binding. As expected (Berg et al., 1999; Price et al., 2001), SB 206553 decreased basal IP accumulation (-70\%), $\left[{ }^{3} \mathrm{H}\right]$-AA release $(-25 \%)$, and $\left[\gamma^{35} \mathrm{~S}\right] \mathrm{GTP}$ binding $(-30 \%)$, indicating that SB 206553 behaves as an inverse agonist toward these three responses (Fig. 1). SB 242084 showed similar inverse agonist activity in reducing $\left[{ }^{3} \mathrm{H}\right]-\mathrm{AA}$ release $(-20 \%)$ and $\left[\gamma^{35} \mathrm{~S}\right] \mathrm{GTP}$ binding $(-30 \%)$; however, at variance with SB 206553, SB 242084 displayed weak agonist activity on IP accumulation. When tested further in a cell line with lower receptor expression levels and no receptor reserve (CHO-1C19; 250 $\mathrm{fmol} / \mathrm{mg}$ protein) (Berg et al., 1999) in which the full agonist 5 -HT increased IP accumulation $235 \pm 27 \%$ above basal, SB 242084 did not change IP accumulation ( $5 \pm 4 \%$; $n=3$ ). Moreover, SB $242084(100 \mathrm{~nm})$ induced a rightward shift of the SB 206553-induced decrease in IP accumulation (Fig. 1a).

\section{Basal extracellular DA concentrations in dialysates from nucleus accumbens and striatum}

All measurements were performed $120 \mathrm{~min}$ after the beginning of perfusion, by which time a steady state was achieved. Absolute basal levels of DA in dialysates, simultaneously collected from the striatum and the nucleus accumbens, did not differ between the different experimental groups throughout the course of the study and were (mean \pm SEM, without adjusting for probe recovery) $14.7 \pm 2.7 \mathrm{pg} / 30 \mu \mathrm{l}$ and $4.3 \pm 0.8 \mathrm{pg} / 30 \mu \mathrm{l}$, respectively $(n=16$ animals chosen randomly from the cohort).

\section{Effect of 5- $\mathrm{HT}_{2 \mathrm{C}}$ compounds on in vivo $\mathrm{DA}$ release in the rat striatum and nucleus accumbens}

The effect of the intraperitoneal administration of increasing doses of SB $206553(1-10 \mathrm{mg} / \mathrm{kg})$, SB $242084(1-10 \mathrm{mg} / \mathrm{kg})$, and Ro-60-0175 $(0.3-3 \mathrm{mg} / \mathrm{kg})$ on DA extracellular levels is shown in Figure 2. Systemic administration of purported 5- $\mathrm{HT}_{2 \mathrm{C}}$ antagonists SB 206553 and SB 242084 differed regarding their effect on DA release. SB 206553 elicited a significant and dose-dependent 

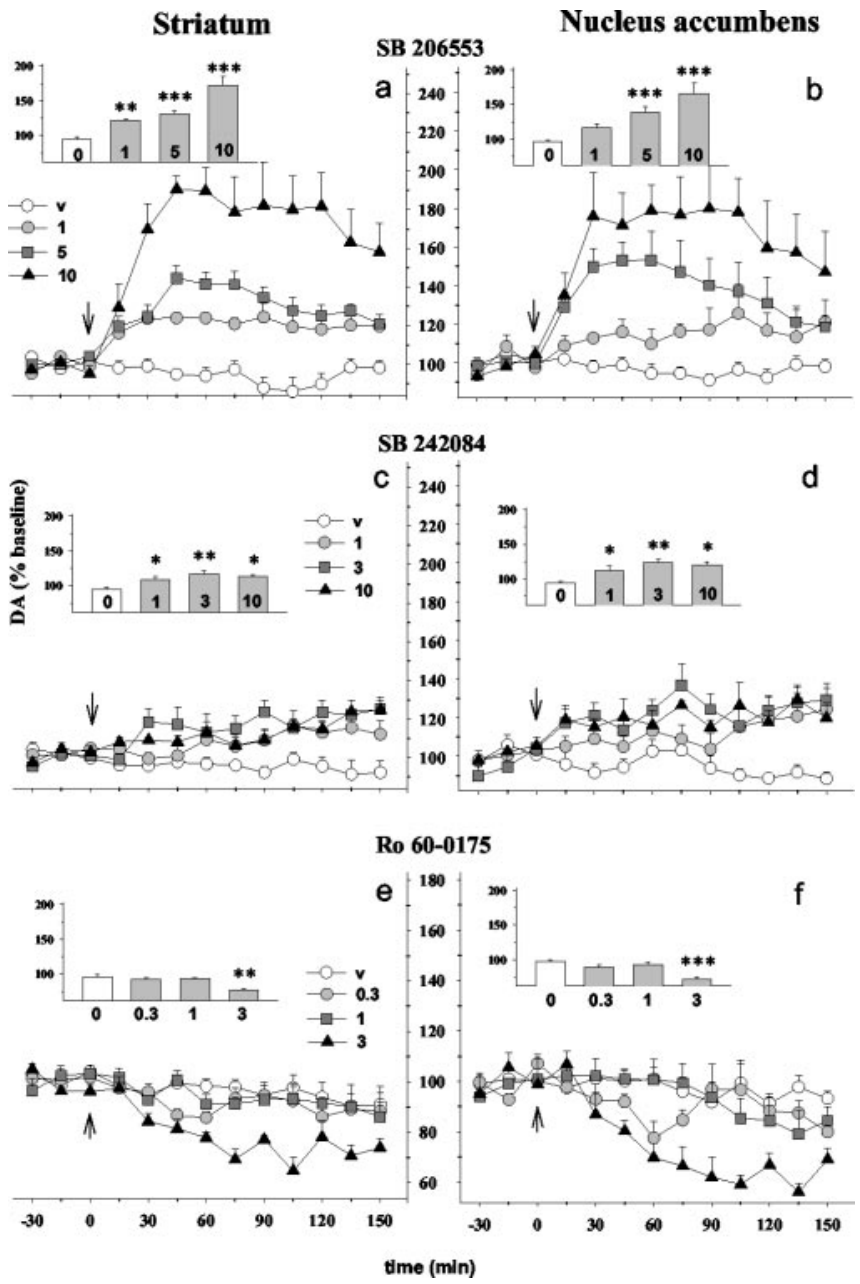

Figure 2. Dose-response effects of $5-\mathrm{HT}_{2 C}$ receptor ligands on basal DA release in the striatum and the nucleus accumbens. The inverse agonist SB $206553(a, b)$, the antagonist SB $242084(c, d)$, and the agonist Ro-60-0175 $(e, f)$ and their corresponding vehicle (v) were administered intraperitoneally (doses in milligrams per kilogram) as indicated by vertical arrows. Data represent mean \pm SEM percentages of baseline in each sample (time courses) or averaged over $2.5 \mathrm{hr}$ monitoring (Insets: doses in milligrams per kilogram indicated in histograms or below) ( $n=4-6$ animals/group). ${ }^{*} p<0.05,{ }^{* *} p<0.01$, and ${ }^{* * *} p<0.001$ versus the vehicle group (Fisher's PLSD test).

increase in DA efflux in the striatum $\left(F_{(3,21)}=26.4 ; p<0.001\right)$ and the nucleus accumbens $\left(F_{(3,21)}=10.5 ; p<0.001\right)$. This effect reached a maximal value within 30-45 min after injection (Fig. $2 a, b)$; the overall magnitude reached approximately $+20,+35$, and $+70 \%$ of baseline in both brain areas after 1,5 , and $10 \mathrm{mg} / \mathrm{kg}$ SB 206553 administration, respectively (Fig. $2 a, b$, insets).

SB 242084 elicited a significant and progressive enhancement of DA efflux in both the striatum $\left(F_{(3,23)}=6.1 ; p<0.01\right)$ and nucleus accumbens $\left(F_{(3,23)}=5.7 ; p<0.01\right)$ (Fig. $\left.2 c, d\right)$. The overall effect was small and reached a maximum at the dose of $3 \mathrm{mg} / \mathrm{kg}$ $(+22$ and $+29 \%$ above vehicle-treated rats in the striatum and nucleus accumbens) (Fig. $2 c, d$, insets).

Intraperitoneal administration of $3 \mathrm{mg} / \mathrm{kg}$, but not 0.3 or 1 $\mathrm{mg} / \mathrm{kg}$, of Ro-60-0175 elicited a significant decrease in DA efflux in the striatum $\left(F_{(3,18)}=7 ; p<0.01\right)$ and the nucleus accumbens $\left(F_{(3,18)}=9.73 ; p<0.001\right)$. This effect started 30 min after Ro$60-0175$ injection and reached a maximal inhibition of 35 and $40 \%$ in the striatum and the nucleus accumbens, respectively (Fig. 2e,f). The overall inhibition induced by Ro-60-0175 was slightly more pronounced in the nucleus accumbens $(-25 \%$
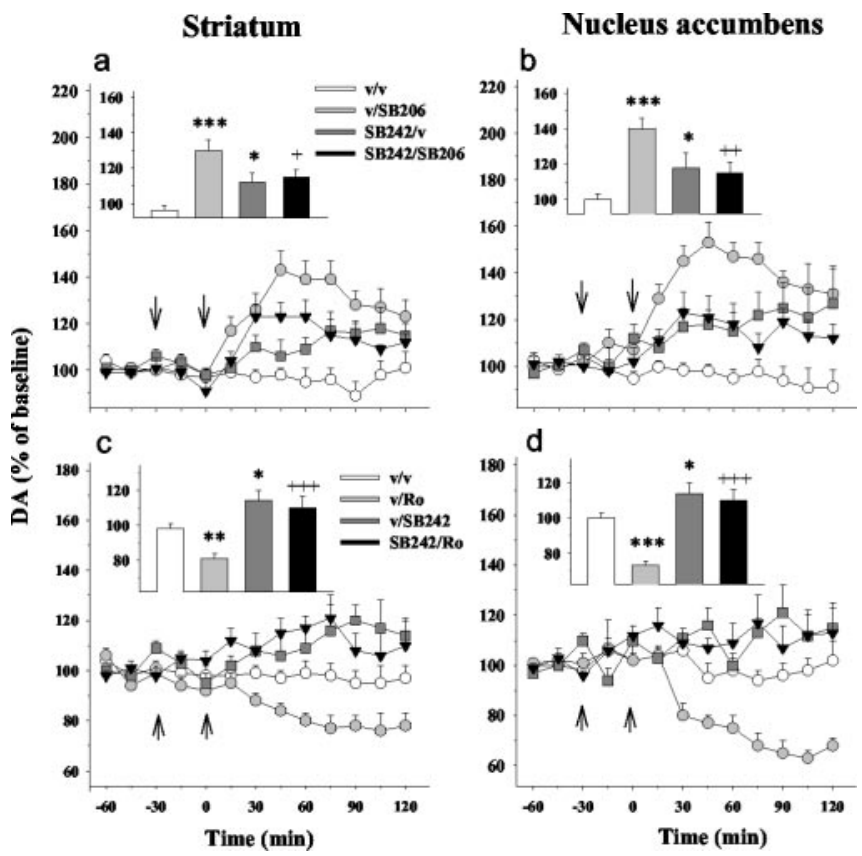

Figure 3. Effect of central $5-\mathrm{HT}_{2 \mathrm{C}}$ receptor blockade on $5-\mathrm{HT}_{2 \mathrm{C}}$ receptor ligands mediated responses on DA release in vivo. Reversal by SB $242084(1 \mathrm{mg} / \mathrm{kg})$ of the DA effects elicited by 5

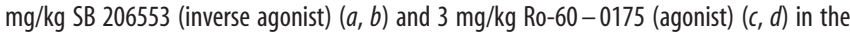
striatum and the nucleus accumbens. SB 242084 (SB242) was administered $30 \mathrm{~min}$ before SB 206553 (SB206) or Ro-60 - 0175 (Ro) as indicated by vertical arrows. Data represent mean \pm SEM percentages of baseline in each sample (time courses) or averaged over $2 \mathrm{hr}$ monitoring (insets) ( $n=6-9$ animals/group). ${ }^{*} p<0.05,{ }^{* *} p<0.01$, and ${ }^{* * *} p<0.001$ versus the vehicle-vehicle (v/v) group and ${ }^{+} p<0.05,{ }^{++} p<0.01$, and ${ }^{+++} p<0.001$ versus the $v / S B 206553$ or $v /$ Ro $-60-0175$ groups (Fisher's PLSD test).

above control values) compared with the striatum (-19\%) (Fig. $2 e, f$, insets).

Effect of SB 242084 on Ro-60-0175- and SB 206553-induced changes in striatal and accumbal DA release

Figure 3, $a$ and $b$, reports that the overall increase in striatal and accumbal DA efflux induced by $5 \mathrm{mg} / \mathrm{kg}$ SB 206553 was prevented by $1 \mathrm{mg} / \mathrm{kg}$ SB $242084\left(F_{(1,23)}=10.3\right.$ and 13.98 for the striatum and the nucleus accumbens, respectively; $p<0.01)$. DA efflux in the SB $242084+$ SB 206553 group was not different from that obtained in the SB 242084 + vehicle group in both regions (Fig. $3 a, b$, insets).

As shown in Figure 3, $c$ and $d$, SB 242084 also impaired the inhibitory effect elicited by $3 \mathrm{mg} / \mathrm{kg}$ Ro-60-0175 in the nucleus accumbens $\left(F_{(1,24)}=5.83 ; p<0.05\right)$. In the striatum, the twoway ANOVA failed to reach significance $\left(F_{(1,24)}=2.62 ; p=\right.$ $0.118)$. Nevertheless, as for the nucleus accumbens, DA extracellular levels in the SB 242084 + Ro-60-0175 group were not significantly different from those obtained in the SB $242084+$ vehicle group in the striatum (Fisher's PLSD after significant oneway ANOVA; $\left.F_{(3,24)}=11 ; p<0.01\right)$.

Of note, the inhibitory effect elicited by $3 \mathrm{mg} / \mathrm{kg}$ Ro-60-0175 was also prevented by $5 \mathrm{mg} / \mathrm{kg}$ SB 206553 in the nucleus accumbens $\left(F_{(1,20)}=28.95 ; p<0.001\right)$ and the striatum $\left(F_{(1,20)}=9.69\right.$; $p<0.01)$. DA extracellular levels in the SB $206553+$ Ro- $60-$ 0175 group were not significantly different from those obtained in the SB 206553 + vehicle group in both brain regions (data not shown). 

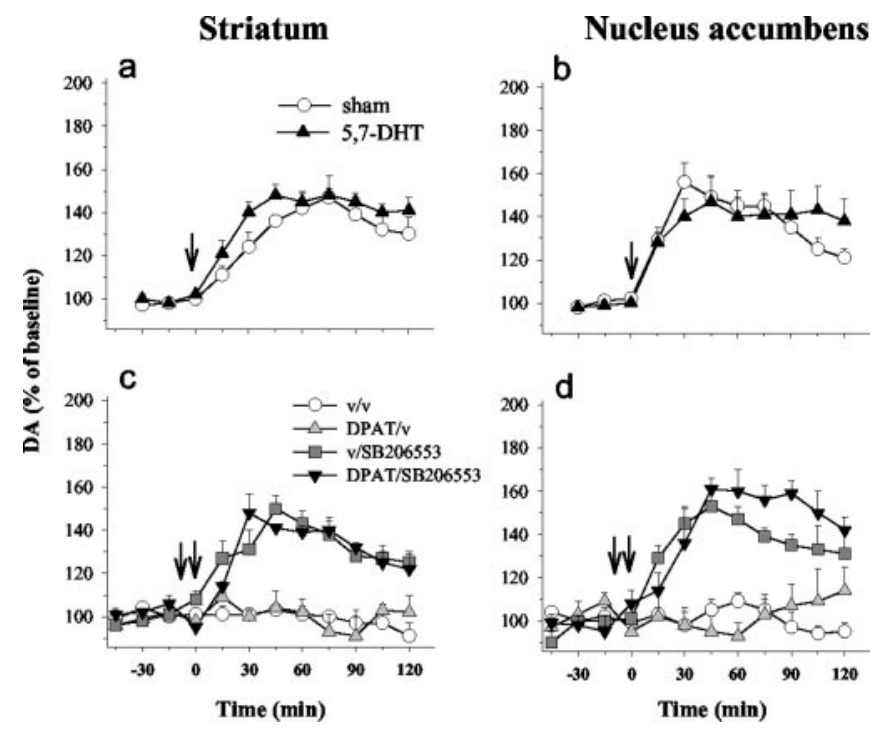

Figure 4. Effect of 5,7-DHT lesion $(a, b)$ or ( \pm )-8-0H-DPAT administration $(c, d)$ on SB 206553-induced DA release in the striatum and the nucleus accumbens. SB $206553(5 \mathrm{mg} / \mathrm{kg}$, i.p.) was administered alone $(a, b)$ or $5 \mathrm{~min}$ after the subcutaneous injection of the $5-\mathrm{HT}_{1 \mathrm{~A}}$ agonist 8-OH-DPAT (DPAT; $0.1 \mathrm{mg} / \mathrm{kg})(c, d)$ (vertical arrows). Data represent mean $\pm \mathrm{SEM}$ percentages of baseline ( $n=4-6$ animals/group).

\section{Effect of 5,7-DHT lesion on SB 206553-induced increase in} striatal and accumbal DA release

Figure 4, $a$ and $b$, reports the effect of SB 206553 on striatal and accumbal DA outflow in vehicle- and 5,7-DHT-treated rats. As expected from our previous experiments (De Deurwaerdère et al., 1998), 5,7-DHT strongly reduced 5-HIAA dialysate content $(-95 \%)$ in both the striatum $(1155 \pm 115 \mathrm{pg} / 30 \mu \mathrm{l}$ and $38 \pm 0.5$ $\mathrm{pg} / 30 \mu \mathrm{l}$, in vehicle- and 5,7-DHT-treated rats, respectively; $p<$ $0.001)$ and the nucleus accumbens $(275 \pm 5 \mathrm{pg} / 30 \mu \mathrm{l}$ and $13 \pm$ $2.9 \mathrm{pg} / 30 \mu \mathrm{l}$, in vehicle- and 5,7-DHT-treated rats, respectively; $p<0.001$ ), revealing the dramatic loss of endogenous 5-HT in 5,7-DHT-treated animals. In contrast, basal DA outflow showed no difference between sham-lesioned and 5-HT-lesioned rats in both the striatum $(14 \pm 2.1 \mathrm{pg} / 30 \mu \mathrm{l}$ and $10 \pm 0.5 \mathrm{pg} / 30 \mu \mathrm{l}$, in vehicle- and 5,7-DHT-treated rats, respectively; NS) and the nucleus accumbens $(4 \pm 0.5 \mathrm{pg} / 30 \mu \mathrm{l}$ and $3 \pm 0.3 \mathrm{pg} / 30 \mu \mathrm{l}$, in vehicle- and 5,7-DHT-treated rats, respectively; NS).

As shown in Figure 4, $a$ and $b$, the 5,7-DHT lesion did not modify the time course or the amplitude of the excitatory effect elicited by $5 \mathrm{mg} / \mathrm{kg}$ SB 206553 on DA extracellular levels in the striatum $\left(F_{(1,8)}=1.6 ; \mathrm{NS}\right)$ and the nucleus accumbens $\left(F_{(1,8)}=\right.$ $0.2 ; \mathrm{NS})$.

\section{Effect of 8-OH-DPAT on SB 206553-induced increase in striatal and accumbal DA release}

To further assess the influence of endogenous 5-HT on the effect of SB 206553, the 5- $\mathrm{HT}_{1 \mathrm{~A}}$ agonist $8-\mathrm{OH}-\mathrm{DPAT}$ was coadministered at a dose $(0.1 \mathrm{mg} / \mathrm{kg})$ known to decrease central 5-HT extracellular levels (Sharp et al., 1989b). As reported in Figure 4, $c$ and $d, 8-\mathrm{OH}-\mathrm{DPAT}$ did not alter the effect of SB $206553\left(F_{(1,19)}=0.1\right.$ in the striatum and 0.29 in the nucleus accumbens; NS). Indeed, 8-OH-DPAT did not modify DA dialysate content in vehicle- or SB 206553-treated rats (Fisher's PLSD test).

\section{Discussion}

The present study provides the first in vivo evidence that constitutive activity of the $5-\mathrm{HT}_{2 \mathrm{C}}$ receptor tonically inhibits striatal and accumbal DA release, thus identifying a new modality of heterologous control regulating basal DA neuron activity.

Striatal and accumbal DA release were enhanced by the purported 5- $\mathrm{HT}_{2 \mathrm{C}}$ antagonists SB 206553 and SB 242084 and inhibited by the $5-\mathrm{HT}_{2 \mathrm{C}}$ agonist Ro-60-0175. These results confirm previous findings proposing that $5-\mathrm{HT}_{2 \mathrm{C}}$ receptors exert both phasic and tonic inhibitory control on DA neuron activity (Di Giovanni et al., 1999; Gobert et al., 2000; De Deurwaerdère and Spampinato, 2001). The performed dose-response experiments allow us to show first that the sensitivity of the nigrostriatal and mesoaccumbens DA pathways is similar to the acute administration of $5-\mathrm{HT}_{2 \mathrm{C}}$ ligands, dampening the proposal of a preferential role of $5-\mathrm{HT}_{2 \mathrm{C}}$ receptors in the control of the mesoaccumbens DA pathway (Di Matteo et al., 2001; Rocha et al., 2002).

Second, they confirm previous sporadic observations (De Deurwaerdère and Spampinato, 2001) that SB 206553 elicited a marked increase in DA release compared with SB 242084 and clearly indicate that SB 206553 is more efficacious than SB 242084 in enhancing DA release. It is unlikely that the $5-\mathrm{HT}_{2 \mathrm{~B}}$ component of SB 206553 may account for its higher efficacy, because selective $5-\mathrm{HT}_{2 \mathrm{~B}}$ agents do not affect basal DA neuron activity (Gobert et al., 2000). The difference observed cannot be explained if both drugs act as simple $5-\mathrm{HT}_{2 \mathrm{C}}$ antagonists to block the effect of endogenous 5-HT. In line with this consideration, administration of the $5-\mathrm{HT}_{1 \mathrm{~A}}$ agonist $8-\mathrm{OH}-\mathrm{DPAT}$ or selective lesion of 5-HT neurons located in the raphe nuclei, two conditions associated with decreased endogenous 5-HT tone (Sharp et al., 1989a,b), did not affect basal DA release in the nucleus accumbens or the striatum (De Deurwaerdère et al., 1998; this study). Taken together, these data highlight the possibility that basal $5-\mathrm{HT}_{2 \mathrm{C}}$ receptor tone on DA release is not strictly related to extracellular levels of 5-HT and that the differential effect of SB 206553 and SB 242084 may be a consequence of distinct intrinsic pharmacological properties.

In favor of this possibility, studies in $\mathrm{CHO}$ cells expressing human $5-\mathrm{HT}_{2 \mathrm{C}}$ receptors expressed at a density to optimize its constitutive receptor activity (Berg et al., 1998) revealed that SB 206553 and SB 242084, although sharing the ability to antagonize IP accumulation induced by agonists (Kennett et al., 1996; 1997), possess distinct pharmacological properties. In agreement with previous data (Berg et al., 1998; Price et al., 2001), we found that SB 206553 behaves as a strong inverse agonist at PLC-, PLA2-, and activation of $\mathrm{G} \alpha_{\mathrm{I}}$-dependent responses coupled to the $5-\mathrm{HT}_{2 \mathrm{C}}$ receptor, respectively. At variance, SB 242084 appears to be a protean ligand (Kenakin, 2001) that is equally as efficacious as SB 206553 toward $\mathrm{PLA}_{2}$ and $\mathrm{G} \alpha_{\mathrm{i}}$ activation but displays lowefficacy agonism toward PLC. According to their pharmacological properties at PLC-dependent responses, SB 242084 induced a rightward shift of the inhibition of IP accumulation elicited by SB 206553. This pharmacological characterization toward three independent intracellular pathways provides further support for the hypothesis of agonist-directed trafficking of receptor stimulus (Kenakin, 1995; Clarke and Bond, 1998) and supports the pleiotropic behavior of ligands at $5-\mathrm{HT}_{2 \mathrm{C}}$ receptors (Berg et al., 1998; Clarke and Bond, 1998). Moreover, these results provide a mechanistic basis to explain the different responsiveness of DA neurons to these ligands and to further evaluate their interaction in vivo.

In line with the above consideration, SB 242084 significantly blocked the increase in striatal and accumbal DA release elicited by SB 206553. Also, SB 242084 reversed the decrease in DA release produced by Ro-60-0175 in both brain regions, although the interaction did not reach statistical significance in the striatum 
(see Results). These findings indicate that the opposite changes of DA release elicited by SB 206553 and Ro-60-0175 are mediated by their action at $5-\mathrm{HT}_{2 \mathrm{C}}$ receptors and suggest, furthermore, that the marked effect of SB 206553 on DA release is related to its inverse agonist activity at central $5-\mathrm{HT}_{2 \mathrm{C}}$ receptors. As anticipated from its inverse agonist profile (Lefkowitz et al., 1993; Morisset et al., 2000), we found that SB 206553 also prevented Ro-60-0175-induced inhibition of DA release in both brain areas. These findings together strongly suggest that endogenous $5-\mathrm{HT}_{2 \mathrm{C}}$ receptors have physiologically relevant constitutive activity in inhibiting both the nigrostriatal and the mesoaccumbens DA pathways. The existence of a constitutive activity of the $5-\mathrm{HT}_{2 \mathrm{C}}$ receptor in vivo, which is compatible with the idea that this receptor tonically controls the excitability of various neuronal networks (Tecott et al., 1995), is also in line with the occurrence of inverse agonism in the $5-\mathrm{HT}_{2}$ regulation of the rabbit nictitating membrane reflex (Harvey et al., 1999).

Because SB 206553 and SB 242084 differ dramatically in their effect on the PLC response, it is tempting to suggest that the prominent increase in DA release produced by SB 206553 may be related to constitutive activity of the $5-\mathrm{HT}_{2 \mathrm{C}}$ receptor toward the PLC effector pathway. Of note, other $5-\mathrm{HT}_{2 \mathrm{C}}$ inverse agonists on PLC-dependent responses, such as mesulergine, ritanserin, or mianserin, may increase basal DA release in vivo (Andersson et al., 1995; Di Matteo et al., 2001), but the weak selectivity of these compounds toward $5-\mathrm{HT}_{2 \mathrm{C}}$ receptors deserves caution in interpreting the data (Di Giovanni et al., 1999). Moreover, the small increase in basal DA release induced by SB 242084 in our study could be consequent to its full inverse agonist activity toward the $\mathrm{PLA}_{2}$ and the $\mathrm{G} \alpha$ i pathways or to its ability to selectively block a small endogenous inhibitory tone exerted by 5 -HT itself at $5-\mathrm{HT}_{2 \mathrm{C}}$ receptors.

5-HT is constitutively released from terminal fields of 5-HT neurons (Sharp et al., 1989a,b), and its continuous presence in the synaptic cleft could confound our interpretation that the $5-\mathrm{HT}_{2 \mathrm{C}}$ receptor is constitutively active in vivo. Nonetheless, we found that SB 206553-stimulated DA release was insensitive to the decrease in 5-HT terminal activity induced by either 5,7-DHT destruction of central 5-HT neurons or 8-OH-DPAT administration. In line with these findings, 8-OH-DPAT did not modify the effect elicited by the $\mu$ opiate agonist morphine on DA release, although this latter was potentiated by SB 206553 (Willins and Meltzer, 1998; Porras et al., 2002). These findings, showing that the efficacy of SB 206653 on DA neuron activity is independent from changes in extracellular levels of 5 -HT, corroborate a recent proposal that the low influence of changes of 5-HT extracellular levels in a biological response might be a direct consequence of the high constitutive tone of native $5-\mathrm{HT}_{2 \mathrm{C}}$ receptors (Niswender et al., 1999). In this respect, RNA editing of the transcript encoding $5-\mathrm{HT}_{2 \mathrm{C}}$ receptors (Burns et al., 1997), by lowering constitutive activity of the native product (Niswender et al., 1999), might represent a determining factor in organizing the strength of $5-\mathrm{HT}_{2 \mathrm{C}}$ receptor influence at central 5-HT synapses (Price et al., 2001).

An aberration in DA signaling in brain is associated with various devastating diseases and conditions such as schizophrenia, Parkinson's disease, and drug addiction, and $5-\mathrm{HT}_{2 \mathrm{C}}$ receptors have been proposed as a useful target for improved treatments of these chronic diseases (Meltzer, 1999; De Deurwaerdère and Chesselet, 2000; Grottick et al., 2000; Wood et al., 2001; Rocha et al., 2002). The fact that inverse agonists effectively behave differently compared with neutral antagonists in vivo brings up important therapeutic perspectives. For instance, several antipsychotic drugs display inverse agonist activity at constitutive $5-\mathrm{HT}_{2 \mathrm{C}}$ receptors (Rauser et al., 2001), and this property could participate in the clinical superiority of some atypical antipsychotics, including clozapine or olanzapine (Rauser et al., 2001). Long-term treatment experiments are warranted to directly address this possibility.

In conclusion, we have shown that constitutively active $5-\mathrm{HT}_{2 \mathrm{C}}$ receptors are responsible for a tonic inhibitory control on nigrostriatal and mesolimbic DA neuronal pathways. These data extend the in vivo identification of constitutive activity of the $5-\mathrm{HT}_{2}$ receptor (Harvey et al., 1999) and bring up additional neurochemical evidence for such an activity of G-proteincoupled receptors from the regulation of histamine metabolism exerted by histamine $\mathrm{H}_{3}$ autoreceptors (Morisset et al., 2000) to the heteroregulation of neuronal network excitability exerted by $5-\mathrm{HT}_{2 \mathrm{C}}$ receptors within the living brain. Our study underscores the need for a better understanding of the pathophysiological role of constitutive receptor activity and of the therapeutic potential of inverse agonism (Niswender et al., 2001; Rauser et al., 2001).

\section{References}

Andersson JL, Nomikos GG, Marcus M, Hertel P, Mathe JM, Svensson TH (1995) Ritanserin potentiates the stimulatory effects of raclopride on neuronal activity and dopamine release selectivity in the mesolimbic dopaminergic system. Naunyn Schmiedebergs Arch Pharmacol 352:374-385.

Barker EL, Westphal RS, Schmidt D, Sanders-Bush E (1994) Constitutively active 5-hydroxytryptamine $2 \mathrm{C}$ receptors reveal novel inverse agonist activity of receptor ligands. J Biol Chem 269:11687-11690.

Barnes NM, Sharp T (1999) A review of central 5-HT receptors and their function. Neuropharmacology 38:1083-1152.

Baumgarten HC, Bjorklund A, Lackenmayer L, Nobin A (1973) Evaluation of the effects of 5,7-dihydroxytryptamine on serotonin and catecholamine neurones in the rat CNS. Acta Physiol Scand 391:1-19.

Berg KA, Maayani S, Goldfarb J, Clarke WP (1998) Pleiotropic behavior of $5-\mathrm{HT}_{2 \mathrm{~A}}$ and 5- $\mathrm{HT}_{2 \mathrm{C}}$ receptor agonists. Ann NY Acad Sci 861:104-110.

Berg KA, Stout BD, Cropper JD, Maayani S, Clarke WP (1999) Novel actions of inverse agonists on $5-\mathrm{HT}_{2 \mathrm{C}}$ receptor systems. Mol Pharmacol 55:863-872.

Burns CM, Chu H, Reuter SM, Hutchinson LK, Canton H, Sanders-Bush E, Emeson RB (1997) Regulation of serotonin-2C receptor G-protein coupling by RNA editing. Nature 387:303-308.

Clarke WP, Bond RA (1998) The elusive nature of intrinsic efficacy. Trends Pharmacol Sci 19:270-276.

De Deurwaerdère P, Chesselet M-F (2000) Nigrostriatal lesions alter oral dyskinesia and c-Fos expression induced by the serotonin agonist 1-(mchlorophenyl)piperazine in adult rats. J Neurosci 20:5170-5178.

De Deurwaerdère P, Spampinato U (2001) The nigrostriatal dopamine system: a neglected target for $5-\mathrm{HT}_{2 \mathrm{C}}$ receptors. Trends Pharmacol Sci 22:502-504.

De Deurwaerdère P, Stinus L, Spampinato U (1998) Opposite change of in vivo dopamine release in the rat nucleus accumbens and striatum that follows electrical stimulation of dorsal raphe nucleus: role of $5-\mathrm{HT}_{3}$ receptors. J Neurosci 18:6528-6538.

Di Chiara G (2002) Nucleus accumbens shell and core dopamine: differential role in behavior and addiction. Behav Brain Res 137:75-114.

Di Giovanni G, De Deurwaerdère P, Di Mascio M, Di Matteo V, Esposito E, Spampinato U (1999) Selective blockade of serotonin-2C/2B receptors enhances mesolimbic and mesostriatal dopaminergic function: a combined in vivo electrophysiological and microdialysis study. Neuroscience 91:587-597.

Di Matteo V, De Blasi A, Di Giulio C, Esposito E (2001) Role of 5- $\mathrm{HT}_{2 \mathrm{C}}$ receptors in the control of central dopamine function. Trends Pharmacol Sci 22:229-232.

Dunnett SB, Robbins TW (1992) The functional role of mesotelencephalic dopamine systems. Biol Rev Camb Philos Soc 67:491-518.

Eberle-Wang K, Mikeladze Z, Uryu K, Chesselet MF (1997) Pattern of expression of the serotonin $2 \mathrm{C}$ receptor messenger RNA in the basal ganglia of adult rats. J Comp Neurol 384:233-247. 
Evans KL, Cropper JD, Berg KA, Clarke WP (2001) Visualizing differences in ligand-induced beta-arrestin-GFP interactions and trafficking between three recently characterized G protein-coupled receptors. J Pharmacol Exp Ther 297:1025-1035.

Gobert A, Rivet J-M, Lejeune F, Newman-Tancredi A, Adhumeau-Auclair A, Nicolas J-P, Cistarelli L, Melon C, Millan MJ (2000) Serotonin ${ }_{2 \mathrm{C}}$ receptors tonically suppress the activity of mesocortical dopaminergic and adrenergic, but not serotonergic, pathways: a combined dialysis and electrophysiological analysis in the rat. Synapse 36:205-221.

Grottick AJ, Fletcher PJ, Higgins GA (2000) Studies to investigate the role of 5-HT(2C) receptors on cocaine- and food-maintained behavior. J Pharmacol Exp Ther 295:1183-1191.

Harvey JA, Welsh SE, Hood H, Romano AG (1999) Effect of 5-HT2 receptor antagonists on a cranial nerve reflex in the rabbit: evidence for inverse agonism. Psychopharmacology 141:162-168.

Herrick-Davis K, Grinde E, Niswender CM (1999) Serotonin 5-HT ${ }_{2 \mathrm{C}}$ receptor RNA editing alters receptor basal activity: implications for serotonergic signal transduction. J Neurochem 73:1711-1717.

Kapur S, Remington G (1996) Serotonin-dopamine interaction and its relevance to schizophrenia. Am J Psychiatry 153:466-476.

Kenakin T (1995) Agonist-receptor efficacy II: agonist trafficking of receptor signals. Trends Pharmacol Sci 16:232-238.

Kenakin T (2001) Inverse, protean, and ligand-selective agonism: matters of receptor conformation. FASEB J 15:598-611.

Kennett GA, Wood MD, Bright F, Cilia J, Piper DC, Gager T, Thomas D, Baxter GS, Forbes IT, Ham P, Blackburn TP (1996) In vitro and in vivo profile of SB 206553, a potent $5-\mathrm{HT}_{2 \mathrm{C}} / 5 \mathrm{HT}_{2 \mathrm{~B}}$ receptor antagonist with anxiolytic-like properties. Br J Pharmacol 117:427-434.

Kennett GA, Wood MD, Bright F, Trail B, Riley G, Holland V, Avenell KY, Stean T, Upton N, Bromidge S, Forbes IT, Brown AM, Middlemiss DN, Blackburn TP (1997) SB 242084, a selective and brain penetrant 5- $\mathrm{HT}_{2 \mathrm{C}}$ receptor antagonist. Neuropharmacology 36:609-620.

Kirby LG, Kreiss DS, Singh A, Lucki I (1995) Effect of destruction of serotonin neurons on basal and fenfluramine-induced serotonin release in striatum. Synapse 20:99-105.

Lefkowitz RJ, Cotecchia S, Samama P, Costa T (1993) Constitutive activity of receptors coupled to guanine nucleotide regulatory proteins. Trends Pharmacol Sci 14:303-307.

Martin JR, Bos M, Jenck F, Moreau J, Mutel V, Sleight AJ, Wichmann J, Andrews JS, Berendsen HH, Broekkamp CL, Ruigt GS, Kohler C, Delft AM (1998) 5- $\mathrm{HT}_{2 \mathrm{C}}$ receptor agonists: pharmacological characteristics and therapeutic potential. J Pharmacol Exp Ther 286:913-924.

Meltzer HY (1999) The role of serotonin in antipsychotic drug action. Neuropsychopharmacology 21:106S-115S.

Morisset S, Rouleau A, Ligneau X, Gbahou F, Tardivel-Lacombe J, Stark H, Schunack W, Ganellin CR, Schwartz J-C, Arrang J-M (2000) High constitutive activity of native $\mathrm{H} 3$ receptors regulates histamine neurons in brain. Nature 408:860-864.
Niswender CM, Copeland SC, Herrick-Davis K, Emeson RB, Sanders-Bush E (1999) RNA editing of the human serotonin 5-hydroxytryptamine 2C receptor silences constitutive activity. J Biol Chem 274:9472-9478.

Niswender CM, Herrick-Davis K, Dilley GE, Meltzer HY, Overholser JC, Stockmeier CA, Emeson RB, Sanders-Bush E (2001) RNA editing of the human serotonin $5-\mathrm{HT}_{2 \mathrm{C}}$ receptor alterations in suicide and implications for serotonergic pharmacotherapy. Neuropsychopharmacology 24:478-491.

Paxinos G, Watson C (1998) The rat brain in stereotaxic coordinates. New York: Academic.

Pellegrino LJ, Cushman AJ (1967) A stereotaxic atlas of the rat brain. New York: Meredith.

Porras G, Di Matteo V, Fracasso C, Lucas G, De Deurwaerdère P, Caccia S, Esposito E, Spampinato U (2002) 5- $\mathrm{HT}_{2 \mathrm{~A}}$ and 5- $\mathrm{HT}_{2 \mathrm{C} / 2 \mathrm{~B}}$ receptor subtypes modulate dopamine release induced in vivo by amphetamine and morphine in both the rat nucleus accumbens and striatum. Neuropsychopharmacology 26:311-324.

Price RD, Weiner DM, Chang MS, Sanders-Bush E (2001) RNA editing of the human serotonin $5-\mathrm{HT}_{2 \mathrm{C}}$ receptor alters receptor-mediated activation of G13 protein. J Biol Chem 276:44663-44668.

Rauser L, Savage JE, Meltzer HY, Roth BL (2001) Inverse agonist actions of typical and atypical antipsychotic drugs at the human 5-hydroxytryptamine(2C) receptor. J Pharmacol Exp Ther 299:83-89.

Rocha BA, Goulding EH, O’Dell LE, Mead AN, Coufal NG, Parsons LH, Tecott LH (2002) Enhanced locomotor, reinforcing, and neurochemical effects of cocaine in serotonin 5-hydroxytryptamine $2 \mathrm{C}$ receptor mutant mice. J Neurosci 22:10039-10045.

Sharp T, Bramwell SR, Clark D, Grahame-Smith DG (1989a) In vivo measurement of extracellular 5-hydroxytryptamine in hippocampus of the anesthetized rat using microdialysis: changes in relation to 5-hydroxytryptaminergic neuronal activity. J Neurochem 53:234-240.

Sharp T, Bramwell SR, Grahame-Smith DG (1989b) 5-HT1 agonists reduce 5-hydroxytryptamine release in rat hippocampus in vivo as determined by brain microdialysis. Br J Pharmacol 96:283-290.

Soubrié P, Reisine TD, Glowinski J (1984) Functional aspects of serotonin transmission in the basal ganglia: a review and in vivo approach using the push-pull cannula technique. Neuroscience 13:605-625.

Tecott LH, Sun LM, Akana SF, Strack AM, Lowenstein DH, Dallman MF, Julius D (1995) Eating disorder and epilepsy in mice lacking 5-HT2c serotonin receptors. Nature 374:542-546.

Willins DL, Meltzer HY (1998) Serotonin 5- $\mathrm{HT}_{2 \mathrm{C}}$ agonists selectively inhibit morphine-induced dopamine efflux in the nucleus accumbens. Brain Res 781:291-299.

Wood MD, Heidbreder C, Reavill C, Ashby Jr CR, Middlemiss DN (2001) 5-HT2C receptor antagonists: potential in schizophrenia. Drug Dev Res $54: 88-94$ 